\title{
Effects of the combination of $\mathrm{As}_{2} \mathrm{O}_{3}$ and AZT on proliferation inhibition and apoptosis induction of hepatoma HepG2 cells following silencing of Egr-I
}

This article was published in the following Dove Press journal:

OncoTargets and Therapy

\author{
Chuan Zhao',* \\ Mei Wangl,* \\ Yu Liu' \\ Yongjuan Liang' \\ Li Han ${ }^{2}$ \\ Che Chen' \\ 'Department of Clinical Laboratory \\ Diagnostics and Molecular Biology, \\ Clinical Medical College, Gansu \\ University of Chinese Medicine, \\ Lanzhou, Gansu, China; ${ }^{2}$ Emergency \\ Research Institution, Lanzhou \\ University Second Hospital, Lanzhou, \\ Gansu, China \\ *These authors contributed equally \\ to this work
}

Context: Previous studies have demonstrated that $3^{\prime}$-azido-3'-deoxythymidine (AZT) and arsenic trioxide $\left(\mathrm{As}_{2} \mathrm{O}_{3}\right)$, traditional chemotherapy agents, can synergically inhibit the growth of hepatocellular carcinoma cells. However, the molecular mechanisms underlying $\mathrm{As}_{2} \mathrm{O}_{3}$ and AZT anti-hepatoma activity are unknown.

Objective: This study aimed to investigate the role of early growth response protein 1 (Egr-1) in the process of $\mathrm{As}_{2} \mathrm{O}_{3}$ combined with AZT inhibiting proliferation and inducing apoptosis of human hepatocellular carcinoma HepG2 cells, and explore the possible mechanism.

Materials and methods: The expression of Egr-1 was silenced using siRNA, and then HepG2 cells were treated with $\mathrm{As}_{2} \mathrm{O}_{3}(2 \mu \mathrm{M})$ and AZT $(20 \mu \mathrm{M})$. The rates of cell inhibition and apoptosis were determined by the 3-(4,5-Dimethylthiazol-2-yl)-2,5-diphenyltetrazoliumbromide (MTT) method and flow cytometry, respectively. The mRNA and protein expression of $\mathrm{p} 53$, caspase-3, and Egr-1 were detected by real-time quantitative polymerase chain reaction and Western blotting, respectively.

Results: The inhibitory rate of $\mathrm{As}_{2} \mathrm{O}_{3}(2 \mu \mathrm{M})$ combined with AZT $(20 \mu \mathrm{M})$ on proliferation of HepG2 cells was significantly higher than that of $\mathrm{As}_{2} \mathrm{O}_{3}$ alone. The combination index (CI) values were $0.2<\mathrm{CI}<0.4$, showing strong synergic effect. After silencing Egr-1, the proliferation inhibition and proapoptotic ability of $\mathrm{As}_{2} \mathrm{O}_{3}$ combined with AZT on HepG2 cells were decreased, and the CI value was greater than 1, showing antagonistic effect. In addition, the expression of p53 and caspase-3 mRNA/protein was also significantly decreased.

Conclusion: The present results show that AZT could increase the sensitization of $\mathrm{As}_{2} \mathrm{O}_{3}$ for inhibiting proliferation and promoting apoptosis of HepG2 cells through regulating the expression of Egr-1, which may control the expression of p53 and caspase-3.

Keywords: $\mathrm{HepG} 2, \mathrm{As}_{2} \mathrm{O}_{3}$, AZT, Egr-1, proliferation, apoptosis

\section{Introduction}

Human hepatocellular carcinoma (HCC) is the most common malignant tumor in the liver and the third leading fatal cancer. ${ }^{1}$ The prognosis for $\mathrm{HCC}$ remains poor, and the latency period is long, mainly due to the propensity for metastatic progression and poor response to pharmacological treatment. ${ }^{2}$ At present, surgical resection remains the only curative method of treatment but is applicable to only $10 \%-20 \%$ of cases, with a $13 \%$ survival rate at 3 years. ${ }^{3}$ Chemotherapy and radiotherapy are still the most important regimens in HCC therapy. However, these two regimens are either not effective enough to destroy the cancer cells or cause significant side effects; therefore, the development of new regimen is desirable.
Correspondence: Che Chen Department of Clinical Laboratory Diagnostics and Molecular Biology, Clinical Medical College, Gansu University of Chinese Medicine, Number 35, Dingxi East Road, Chengguan, Lanzhou 730000,

Gansu, China

Email chen72123@163.com 
Arsenic trioxide $\left(\mathrm{As}_{2} \mathrm{O}_{3}\right)$, which is an active ingredient in traditional Chinese medicine, has been used successfully for treating acute promyelocytic leukemia (APL) ${ }^{4}$ and is also effective in the treatment of solid tumors, including human hepatoma and breast cancer. ${ }^{5,6}$ However, this compound has not been widely used because of its toxicity. It is necessary to minimize the dosage of $\mathrm{As}_{2} \mathrm{O}_{3}$ without weakening its anticancer effects.

3'-Azido-3'-deoxythymidine (AZT), a powerful inhibitor of reverse transcriptase, has been used in Phase I and II clinical trials, either alone or in combination with other drugs, in the treatment of gastrointestinal cancers, and some cases of tumor regression have been reported. ${ }^{7,8}$ In previous studies, we reported that $\mathrm{As}_{2} \mathrm{O}_{3}$ combined with AZT has a significantly synergic effect on inhibiting the hepatoma cell proliferation (combination index $[\mathrm{CI}]<1$ ) and inducing its apoptosis. ${ }^{9}$ Furthermore, our results showed that $\mathrm{As}_{2} \mathrm{O}_{3}$ combined with AZT also synergically inhibited the migration and invasion of HepG2 cells. ${ }^{10,11}$ However, its anticancer targets are largely unknown.

Early growth response protein 1 (Egr-1) is an important nuclear transcription factor, which belongs to the early gene family. Some studies showed that Egr-1 suppressed tumors by regulating downstream target genes such as TGF- $\beta$, cyclin D1, c-jun, PTEN, p53, and P21. ${ }^{12-14}$ Shan et al reported that Egr-1 expression was downregulated in hepatocellular carcinoma, and reexpression of Egr-1 decreased cell growth and tumorigenicity in nude mice. ${ }^{15}$ Of note, it has been reported that Egr-1 expression level correlates with sensitivity to chemo-drugs in cancer cells. ${ }^{16}$

In the present study, we used the electroporation method of Egr-1 siRNA to explore the role of Egr-1 in HepG2 cells treated by $\mathrm{As}_{2} \mathrm{O}_{3}$ combined with AZT, and the effect of Egr-1 on some tumor-associated genes was also observed in an attempt to provide the molecular basis for the clinical application of $\mathrm{As}_{2} \mathrm{O}_{3}$ combined with AZT in hepatocellular carcinoma.

\section{Materials and methods Chemicals and reagents}

AZT and 3-(4,5-Dimethylthiazol-2-yl)-2,5-diphenyltetrazoliumbromide (MTT) were purchased from Sigma Chemical Co. (St Louis, MI, USA); $\mathrm{As}_{2} \mathrm{O}_{3}$ was obtained from Shui Kou Shan Mining Bureau of Heng Yang Industrial Company (Hengyang, China); other cell culture supplies were purchased from GE Healthcare - HyClone (Logan, UT, USA); the antibodies to caspase-3, p53, and $\beta$-actin were purchased from ImmunoWay Biotechnology Co. (Newark, DE, USA); peroxidase-conjugated AffiniPure goat anti-rabbit $\operatorname{IgG}(\mathrm{H}+\mathrm{L})$ was purchased from ZSGB-BIO Co. (Beijing, China); and real-time reverse transcriptase polymerase chain reaction
(RT-PCR)-related reagents were purchased from Promega Corporation (Fitchburg, WI, USA).

\section{Cell culture}

The HHC cell lines HepG2 were purchased from JRDUN Biotechnology (Shanghai) Co. Ltd. (Shanghai, China). The HHC cell lines HepG2 was cultured in DMEM with high glucose content containing $10 \%$ heat-inactivated fetal calf serum, $100 \mathrm{IU} / \mathrm{mL}$ penicillin/streptomycin at $37^{\circ} \mathrm{C}$ and incubated in a $5 \% \mathrm{CO}_{2}$ humidified atmosphere. Cells were harvested in logarithmic phase for experiments.

\section{Cell electrotransfection}

HepG2 cells were electrotransfected according to the manufacturer's recommendations (Nucleofector I nuclear transfection apparatus and Amaxa ${ }^{\circledR}$ Cell Line Nucleofector ${ }^{\circledR}$ Kit L, Lonza, Basel, Switzerland) and were divided into three groups: mock (adding the same amount of culture medium), negative control (NC; transfection of non-specific sequence), and Egr1-siRNA (transfected with Egr-1 siRNA) groups. The Egr-1 siRNA segment sense strand is 5'-CCCGGUUACUACCUCUUAUTT- 3 ', and the antisense strand is $5^{\prime}$-AUAAGAGGUAGUAACCGGGTT- $3^{\prime}$. Furthermore, a GFP group (HepG2/GFP, transfect green fluorescent protein) was designed to observe the transfection efficiency under fluorescence microscope. The transfection efficiency of Egr-1 siRNA was also detected by real-time quantitative polymerase chain reaction (qPCR) and Western blotting.

\section{Cell proliferation assay}

Drug treatment was initiated after the cells had begun attaching to the growth surface. The effects of $\mathrm{As}_{2} \mathrm{O}_{3}$ and AZT on HepG2 survival were determined using the MTT reduction assay described earlier, with minor modifications. In brief, $5 \times 10^{3}$ cells were plated in 96 -well plates in $100 \mathrm{~mL}$ of a regular medium per well. After $24 \mathrm{~h}$ growth, the cells were treated with $\mathrm{As}_{2} \mathrm{O}_{3}(2 \mu \mathrm{mol} / \mathrm{L})$ and AZT $(10,20 \mu \mathrm{mol} / \mathrm{L})$ for $72 \mathrm{~h}$. Untreated control and treated cells were incubated with $10 \mu \mathrm{L}$ of MTT ( $5 \mathrm{mg} / \mathrm{mL}$ in serum-free medium) for $4 \mathrm{~h}$ before the end of the incubation period. One hundred microliters of lysis solution $(10 \% \mathrm{SDS}$ in $0.01 \mathrm{~mol} / \mathrm{L}$ of $\mathrm{HCl})$ were then added and another $24 \mathrm{~h}$ culture was made. The cell survival fraction was measured at absorbance (A) $490 \mathrm{~nm}$ on a microplate reader (Bio-Rad Laboratories Inc., Hercules, CA, USA). Assays were carried out in triplicate. The proliferation and inhibition rate of cells were calculated, respectively, as follows:

$$
\begin{aligned}
& \text { Proliferation rate }(\%) \\
& =\frac{\text { Mean A490 of experiment A490 }}{\text { A } 490 \text { of control }} \times 100 \%
\end{aligned}
$$


Inhibition rate $(\%)$

$$
=1-\left(\frac{\text { Mean A490 of experiment }}{\text { A490 of A490 of control }}\right) \times 100 \%
$$

\section{Synergy determination}

The synergic effect between AZT and $\mathrm{As}_{2} \mathrm{O}_{3}$ was analyzed using the $\mathrm{CI}$ method. Concentration effect curves calculated for each drug, both separately and in combination, were applied to determine the amount of each drug, either separately or in combination, required to achieve a given level of effect. The CI was calculated as follows:

$$
\mathrm{CI}=\frac{\mathrm{IC}_{\mathrm{A}, \mathrm{B}}}{\mathrm{IC}_{\mathrm{A}}}+\frac{\mathrm{IC}_{\mathrm{B}, \mathrm{A}}}{\mathrm{IC}_{\mathrm{B}}}
$$

$\mathrm{IC}_{\mathrm{A}}$ and $\mathrm{IC}_{\mathrm{B}}$ are the concentrations of $\mathrm{A}$ and $\mathrm{B}$ needed to produce a given level of cytotoxicity when used separately, whereas $\mathrm{IC}_{\mathrm{A}, \mathrm{B}}$ and $\mathrm{IC}_{\mathrm{B}, \mathrm{A}}$ are the concentrations needed to produce the same effect when used in combination. ${ }^{9} \mathrm{~A} \mathrm{CI}$ value of 1 indicates an additive interaction, values less than 1 indicate a synergic action, and values greater than 1 indicate antagonistic interaction.

\section{Apoptosis assessment}

Detection of apoptotic cells was carried out by annexin V-fluorescein isothiocyanate/propidium iodide (PI) staining. Cells of the three group were plated onto sixwell plates $\left(1 \times 10^{5}\right.$ cells/well $)$ and grown overnight to allow for cell attachment. They were then treated in the absence (control) or presence of $\mathrm{As}_{2} \mathrm{O}_{3}(2 \mu \mathrm{mol} / \mathrm{L})+\mathrm{AZT}$ $(20 \mu \mathrm{mol} / \mathrm{L})$ for $48 \mathrm{~h}$. At the end of the treatment, the cells were harvested, washed with PBS, resuspended in $100 \mu \mathrm{L}$ of binding buffer, and then incubated with $5 \mu \mathrm{L}$ of annexin $\mathrm{V}$ and $5 \mu \mathrm{L}$ of PI for $30 \mathrm{~min}$ at room temperature in the dark according to the manufacturer's instructions (BD Biosciences, San Jose, CA, USA). The samples were acquired on a FACScan flow cytometer (BD Biosciences) and analyzed with CellQuest Software (BD Biosciences). The amount of apoptosis was determined as the percentage of annexin $\mathrm{V}^{+} / \mathrm{PI}^{-}$.

\section{Real-time PCR analysis}

After $48 \mathrm{~h}$ of drug treatment, total RNA was extracted from cells using Trizol reagent. Reverse transcription was performed using Promega cDNA Synthesis Master mix (Promega Corporation) with 50 ng RNA per $25 \mu \mathrm{L}$ of reaction mixture. For real-time PCR, we used the ABI System 7500 fast-real-time PCR (Thermo Fisher Scientific,
Waltham, MA, USA) in standard mode. The total $25 \mu \mathrm{L}$ reaction system contained $12.5 \mu \mathrm{L}$ qPCR Master Mix, $1 \mu \mathrm{L}$ forward/reverse primers, $0.25 \mu \mathrm{L} 5$-carboxy-X-rhodamine, $8.25 \mu \mathrm{L} \mathrm{ddH_{2 }} \mathrm{O}$, and $2 \mu \mathrm{L}$ templates. The experiments were performed three times. PCR products were normalized against the housekeeping gene $\beta$-actin, and measurements between samples were compared by cycle threshold $(\mathrm{Ct})$. The primers used in real-time PCR are as in Table 1. PCR was performed for Egr-1 or $\beta$-actin transcription as follows: denaturation at $94^{\circ} \mathrm{C}$ for 2 min was followed by 40 cycles of denaturation at $94^{\circ} \mathrm{C}$ for $15 \mathrm{~s}$, annealing at $58^{\circ} \mathrm{C}$ for $45 \mathrm{~s}$, and elongation at $60^{\circ} \mathrm{C}$ for $30 \mathrm{~s}$, followed by a final elongation step at $60^{\circ} \mathrm{C}$ for $2 \mathrm{~min}$.

\section{Immunoblot analysis}

Western blotting was performed using standard techniques. Three groups of cells were seeded at $1 \times 10^{5}$ cells $/ \mathrm{mL}$ in $25 \mathrm{~mL}$ culture flasks and then treated with $\mathrm{As}_{2} \mathrm{O}_{3}(2 \mu \mathrm{mol} / \mathrm{L})$ and AZT $(20 \mu \mathrm{mol} / \mathrm{L})$ and further incubated for $48 \mathrm{~h}$. Cells were washed twice with PBS buffer and lysed in 1\% Triton lysis buffer (1\% Triton X-100, 50 mM Tris- $\mathrm{HCl}$ pH 7.4, $150 \mathrm{mM}$ $\mathrm{NaCl}, 10 \mathrm{mM}$ EDTA, $100 \mathrm{mM} \mathrm{NaF}, 1 \mathrm{mM} \mathrm{Na} \mathrm{VO}_{4}, 1 \mathrm{mM}$ PMSF, and $2 \mathrm{mg} / \mathrm{mL}$ aprotinin) on ice, then centrifuged at $10,000 \mathrm{~g}$ for $10 \mathrm{~min}$ to collect the supernatant. Protein concentrations were determined with a Bio-Rad protein assay. Total proteins $60 \mu \mathrm{g}$ were subjected to sodium dodecyl sulfate-polyacrylamide gel ectrophoresis (SDS-PAGE) and transferred to polyvinylidine diflouride filter (PVDF) membranes (Hoffman-La Roche Ltd., Basel, Switzerland). Membranes were blocked with 5\% skim milk in Tris-buffered saline + Tween (TBST) (10 mM Tris, $\mathrm{pH} 7.4,150 \mathrm{mM}$ $\mathrm{NaCl}$, and $0.1 \%$ Tween 20 ) at room temperature for $2 \mathrm{~h}$ and incubated with the corresponding primary antibodies at room temperature for $2 \mathrm{~h}$. After washing with TBST, the membrane was reacted with the appropriate horseradish peroxidase-conjugated secondary antibodies for $2 \mathrm{~h}$ at room temperature. After extensive washing with TBST, proteins were visualized by chemiluminescent reagents. Blots were then detected with Image Lab software.

Table I Primer sequence

\begin{tabular}{ll}
\hline Gene & Primer sequence $\left(\mathbf{5}^{\prime} \rightarrow \mathbf{3}^{\prime}\right)$ \\
\hline Egr-I & Forward: CAGCTTGGTCAGTGGCCTAGT \\
& Reverse: AATGTCAGTGTTCGGCGTGG \\
p53 & Forward: TCGAAATGTTCCGAGAGCTGAAT \\
& Reverse: GTCTGAGTCAGGCCCTTCTGTCTT \\
Caspase-3 & Forward: AAATACCAGTGGAGGCCGAC \\
& Reverse: TTTCAGCTAGGCACAAAGCG \\
$\beta$-actin & Forward: TGGCACCCAGCACAATGAA \\
& Reverse: CTAAGTCATAGTCCGCCTAGAAGCA \\
\hline
\end{tabular}




\section{Statistical analysis}

Each experiment was performed in triplicate, and all the data were processed with SPSS 17.0 software. The results were analyzed by two-way ANOVA and Tukey's b test. $P$-value $<0.05$ was considered statistically significant.

\section{Results}

\section{Transfection efficiency}

Since the GFP gene is transfected into the cell, the GFP protein can be expressed in the cell and emit green fluorescence. Therefore, the transfection efficiency can be judged by observing the number of green fluorescent cells under fluorescence microscopy. As shown in Figure 1, the green fluorescent cells were significantly increased at $10 \mathrm{~h}$, so the transfection efficiency could be detected at $24 \mathrm{~h}$. The qPCR result showed that the transfection efficiency was over $75 \%$ (Figure 2), which could meet the experimental requirements.

\section{The effects of Egr-I on HepG2 cell proliferation}

After Egr-1 siRNA transfection, an MTT assay was used to detect the proliferation of the three groups. Table 1 shows that the cell proliferation rate of $\mathrm{HepG} 2 /$ si-RNA group was
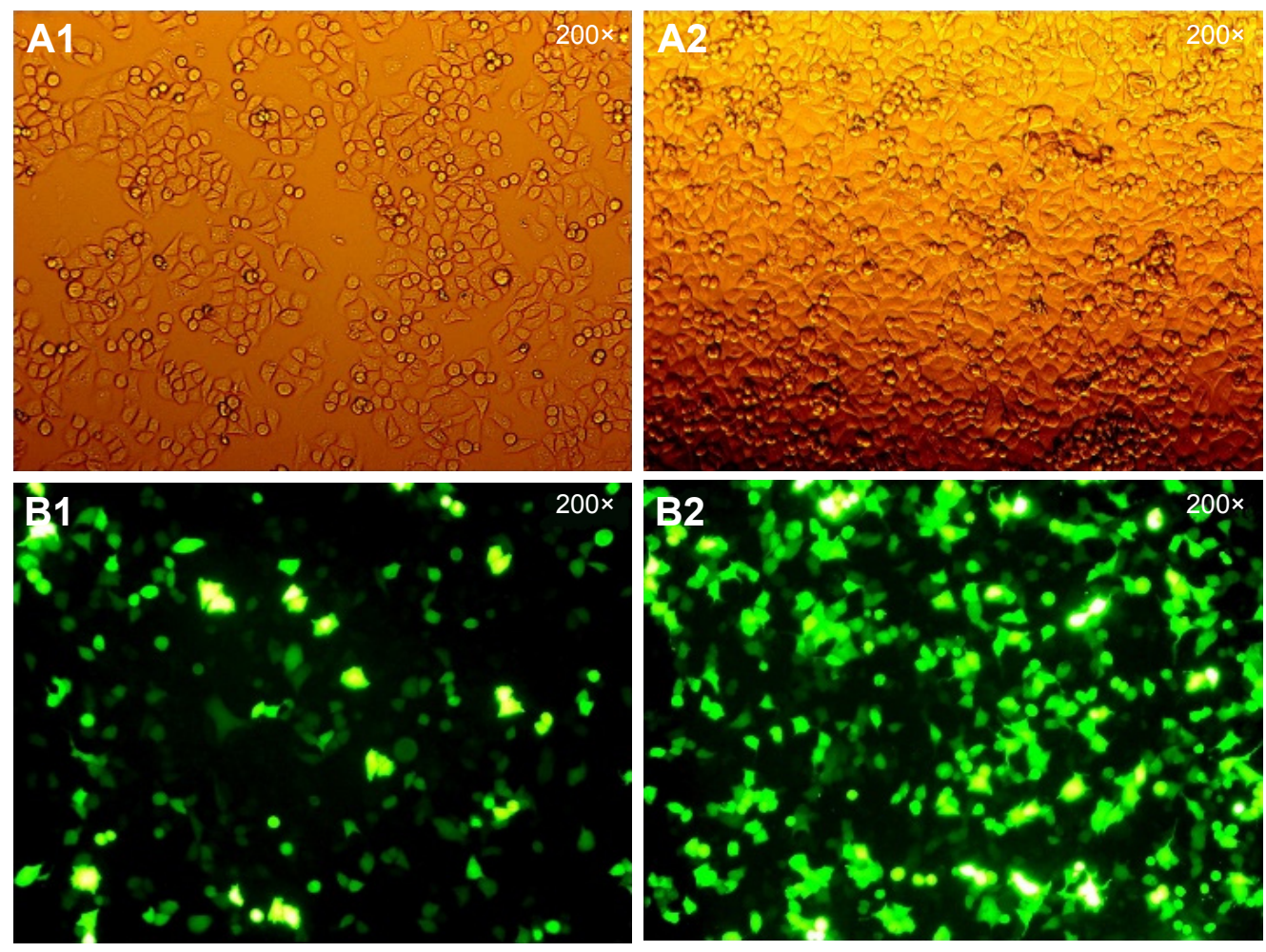

Figure I The HepG2 cells were transfected with Egr-I siRNA.

Notes: (AI) and (A2) show the cells which were observed under phase contrast microscope at 10 and 24 h, respectively, 200x; (BI) and (B2) show the cells which were observed under fluorescence microscope at 10 and $24 \mathrm{~h}$, respectively, 200×. The transfected cells emitted green fluorescence.

Abbreviation: Egr-I, early growth response protein I.

significantly increased at 24 and $48 \mathrm{~h}$ compared with the $\mathrm{NC}$ group (HepG2/NC) and the mock group $(P<0.01)$. The cell proliferation rate of the $\mathrm{NC}$ group at 24,48 , and $72 \mathrm{~h}$ decreased slightly, but the difference was not statistically significant compared with the mock group $(P>0.05)$. However, the cell proliferation rate of HepG2/si-RNA group at $72 \mathrm{~h}$ was not significantly different compared with the NC group (HepG2/NC) and the mock group, which could be due to the decrease in the effect of silencing Egr-1 (Table 2).

\section{The effect of the combination of $\mathrm{As}_{2} \mathrm{O}_{3}$ and AZT on growth of HepG2 cells}

The MTT assay results showed that $2 \mu \mathrm{mol} / \mathrm{L} \mathrm{As}_{2} \mathrm{O}_{3}$ alone had slightly inhibitory effect on the proliferation of HepG2 cells, but there was no statistically significant difference between three groups $(P>0.05)$. Compared with the $\mathrm{NC}$ and the mock groups, the inhibition effect of 10 and $20 \mu \mathrm{mol} / \mathrm{L}$ AZT on HepG2/siRNA group was decreased $(P<0.05)$. Compared with the single drug group, $2 \mu \mathrm{mol} / \mathrm{L}$ $\mathrm{As}_{2} \mathrm{O}_{3}$ combined with 10 or $20 \mu \mathrm{mol} / \mathrm{L}$ AZT significantly enhanced the inhibition effect of HepG2 cells of mock and $\mathrm{NC}$ groups. The difference was statistically significant $(P<0.01)$. However, after transfection of Egr-1 siRNA, the 


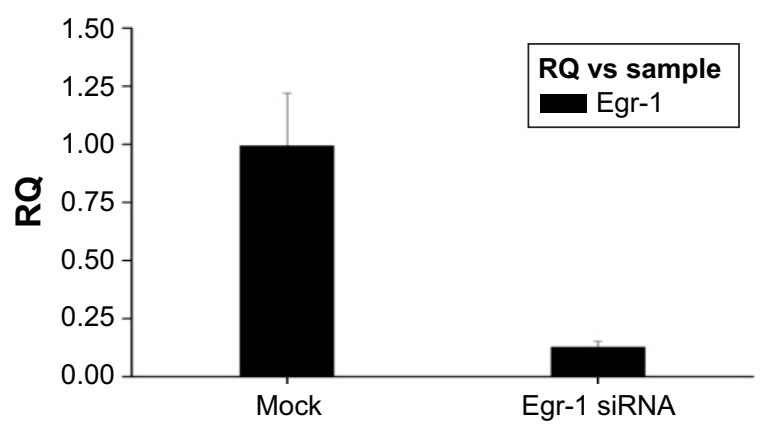

Figure 2 qPCR method to detect transfection efficiency.

Abbreviations: Egr-I, early growth response protein I; qPCR, real-time quantitative polymerase chain reaction; $\mathrm{RQ}$, relative quantity.

inhibition effect of the combinations of $\mathrm{As}_{2} \mathrm{O}_{3}$ and $\mathrm{AZT}$ on the proliferation of HepG2 cells was dramatically decreased $(P<0.05)$ (Figure 3).

\section{Synergic effect of the combination of $\mathrm{As}_{2} \mathrm{O}_{3}$ and AZT}

The synergic effect of combination of $\mathrm{As}_{2} \mathrm{O}_{3}$ and $\mathrm{AZT}$ at $72 \mathrm{~h}$ was analyzed by Calcusyn 2.0 software (Table 3 ). The results showed that after the HepG2 cells of the non-specific control group and the control group were treated with $\mathrm{As}_{2} \mathrm{O}_{3}$ combined with AZT, the $\mathrm{CI}$ values were $0.2<\mathrm{CI}<0.4$, showing strong synergic effect. However, the CI value of the siRNA group was greater than 1, showing antagonistic effect.

\section{Effects of $\mathrm{As}_{2} \mathrm{O}_{3}$ and AZT on apoptosis of HepG2 cells}

The results of flow cytometry showed that the apoptotic rate of HepG2 cells treated by $\mathrm{As}_{2} \mathrm{O}_{3}(2 \mu \mathrm{mol} / \mathrm{L})$ combined with AZT $(20 \mu \mathrm{mol} / \mathrm{L})$ was significantly higher than that of the control group $(P<0.05)$. Compared with the mock and NC groups, the cell apoptotic rate of HepG2/siRNA group was significantly decreased $(P<0.01)$. The difference between blank control group and $\mathrm{NC}$ group was not significant. The results indicated that $\mathrm{As}_{2} \mathrm{O}_{3}$ combined with AZT could promote the apoptosis of HepG2 cells. After silencing Egr-1, the effect was attenuated (Figure 4).

Table 2 Cell proliferation rate after transfection

\begin{tabular}{llll}
\hline Group & $\mathbf{2 4} \mathbf{h}$ & $\mathbf{4 8} \mathbf{h}$ & $\mathbf{7 2} \mathbf{~}$ \\
\hline Mock & $100.00 \pm 10.13$ & $100.00 \pm 10.29$ & $100.00 \pm 10.26$ \\
HepG2/NC & $97.73 \pm 11.67$ & $98.14 \pm 12.14$ & $94.96 \pm 10.17$ \\
HepG2/siRNA & $135.39 \pm 12.14^{\mathrm{a}, \mathrm{b}, *}$ & $137.15 \pm 12.3^{\mathrm{a}, \mathrm{b}, *}$ & $95.32 \pm 10.31$ \\
\hline
\end{tabular}

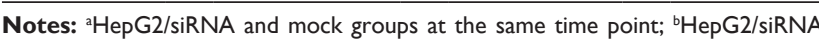
and HepG2/NC groups at the same time point; $* P<0.05$. Data presented as mean $\pm \mathrm{SD}, \%, \mathrm{n}=3$.

Abbreviation: NC, negative control.
The combination of $\mathrm{As}_{2} \mathrm{O}_{3}$ and AZT promotes the expression of Egr-I mRNA/protein expression

As shown in Figure 5A, Egr-1 mRNA expression level of Egr-1 siRNA group was significantly lower than that of the NC group and blank control group after electrotransfection with Egr-1 siRNA for $24 \mathrm{~h}(P<0.01)$. Furthermore, the Egr-1 mRNA expression level of the Egr-1 siRNA group is only equivalent to about one-tenth before transfection.

As shown in Figure $5 \mathrm{~B}$, the combination of $\mathrm{As}_{2} \mathrm{O}_{3}$ $(2 \mu \mathrm{mol} / \mathrm{L})$ and AZT $(20 \mu \mathrm{mol} / \mathrm{L})$ significantly upregulated Egr-1 mRNA expression of HepG2 cell compared with the control group at $48 \mathrm{~h}(P<0.05)$. There was no significant difference between the NC and mock groups. However, the expression level of Egr-1 mRNA in the Egr-1 siRNA group was also significantly increased under the action of the drug, which may be because the blocking effect of Egr-1 siRNA is attenuated at $48 \mathrm{~h}$. The Western blotting results showed that the protein level of Egr-1 was consistent with the mRNA level (Figure 6).

\section{The expression of Egr-I, p53, and caspase-3 in HepG2 cells treated with $\mathrm{As}_{2} \mathrm{O}_{3}$ combined with AZT following Egr-I siRNA}

The results of qPCR showed that the expression of p53 and caspase-3 mRNA in the Egr-1 siRNA group was significantly lower than that in mock group or HepG2/NC group $(P<0.01)$. There was no significant difference between the mock group and the NC group $(P>0.05)$ (Figure 7). The Western blotting results showed that the protein level of p53 and caspase-3 was consistent with the mRNA level (Figure 8).

\section{Discussion}

Arsenic, a metalloid that is universally distributed in nature, is considered to be one of the most toxic xenobiotics. In the 1970s, arsenic was proven to be a highly effective agent in the treatment of APL, and there has been significant progress since then. Recent in vitro experiments have indicated that $\mathrm{As}_{2} \mathrm{O}_{3}$ might be effective in the treatment of solid tumors, such as hepatoma, gastric carcinoma, and breast carcinoma. ${ }^{17-19}$ In addition, $\mathrm{As}_{2} \mathrm{O}_{3}$ can promote apoptosis and differentiation and inhibit proliferation of cancer cells and telomerase activity. ${ }^{20,21}$ However, several reports demonstrated that malignant solid tumors are insensitive to low dose of $\mathrm{As}_{2} \mathrm{O}_{3} \cdot{ }^{22}$ Furthermore, toxic effects of high-dose 

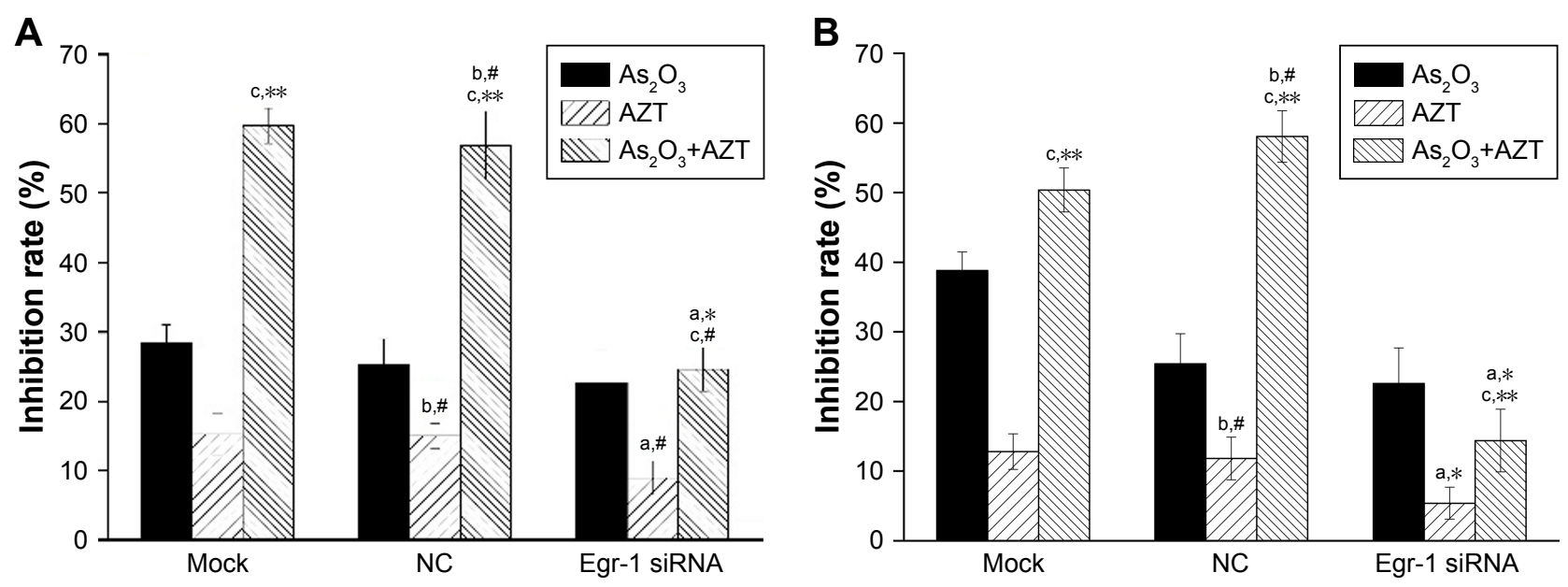

Figure 3 Effect of $\mathrm{As}_{2} \mathrm{O}_{3}$ combined with AZT on cell proliferation inhibition.

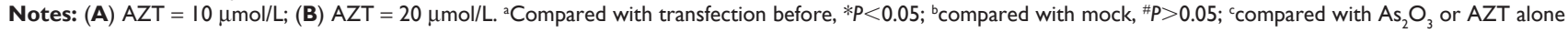
of the same group, ${ }^{* *} P<0.01$, ${ }^{\# P}>0.05$.

Abbreviations: $\mathrm{As}_{2} \mathrm{O}_{3}$, arsenic trioxide; AZT, 3'-azido-3'-deoxythymidine; Egr-I, early growth response protein I; NC, negative control.

$\mathrm{As}_{2} \mathrm{O}_{3}$ also seriously limits its clinical application. Of note, more and more studies have shown that the combination of $\mathrm{As}_{2} \mathrm{O}_{3}$ with other drugs is effective in enhancing efficacy and reducing the use of doses so as to reduce side effects. In an $\mathrm{As}_{2} \mathrm{O}_{3}$ and tretinoin integrated treatment protocol for patients newly diagnosed with APL, joint treatment showed a synergistic effect and leaded to a high clinical complete remission $(\mathrm{CR})$ rates. ${ }^{23,24}$

It has been proven that AZT has excellent inhibition effects and chemo-therapeutic sensitization on a variety of tumors; ${ }^{25-27}$ one possible mechanism is the inhibition of telomerase activity. ${ }^{28}$ Moreover, it has been reported that Pt-AZT could downregulate Bcl-2 expression and inhibit the growth of hepatocellular carcinoma in mice. ${ }^{29}$ However, the dosage of AZT alone needed in treatment of tumors can cause severe toxic side effects; furthermore, the problem of multiple drug resistance occurs when a large dose is used, so restricting the further application of AZT as a clinical antitumor agent. ${ }^{30,31}$ In some recent studies, AZT exhibited significant synergistic therapeutic with other drugs for tumors in a safe dosage range. ${ }^{32-34}$ Chau et al ${ }^{35}$ suggested

Table $3 \mathrm{Cl}$ value of combination of $\mathrm{As}_{2} \mathrm{O}_{3}$ and $\mathrm{AZT}$ in the three groups of cells $(72 \mathrm{~h})$

\begin{tabular}{llll}
\hline $\begin{array}{l}\mathbf{A s}_{2} \mathbf{O}_{3}+\mathbf{A Z T} \\
(\mu \mathrm{mol} / \mathrm{L})\end{array}$ & Groups & Fa & $\mathbf{C l}$ \\
\hline $2+10$ & Mock & 0.608 & 0.174 \\
& HepG2/NC & 0.583 & 0.193 \\
& HepG2/siRNA & 0.243 & 1.032 \\
$2+20$ & Mock & 0.518 & 0.261 \\
& HepG2/NC & 0.484 & 0.303 \\
& HepG2/siRNA & 0.153 & 3.328 \\
\hline
\end{tabular}

Abbreviations: $\mathrm{As}_{2} \mathrm{O}_{3}$, arsenic trioxide; $\mathrm{AZT}, 3^{\prime}$-azido-3'-deoxythymidine; $\mathrm{Cl}$, combination index; Fa, ratio of the fraction affected; NC, negative control. that the combination of azacytidine with $\mathrm{As}_{2} \mathrm{O}_{3}$ would be a logical drug combination for treatment of AML in the future. Wang et $\mathrm{al}^{36}$ reported that the combination of AZT with emodin could co-inhibit the proliferation of leukemia KG-1a cells.

Our previous studies have found that the combination of AZT and $\mathrm{As}_{2} \mathrm{O}_{3}$ has a significant synergistic effect (co-index $\mathrm{CI}<1$ ) on hepatocellular carcinoma, which can reduce the side effects and significantly improve the therapeutic effect of the two compounds. According to some clues, single low doses of $\mathrm{As}_{2} \mathrm{O}_{3}$ and AZT did not promote activity caspase-3, but the combination of the two compounds significantly promoted the activity of caspase- $3,{ }^{9}$ the most important mediators of apoptosis.

Egr-1, a zinc finger transcription factor, has been found to be rapidly induced with a broad range of extracellular stimuli, thus mediating growth, proliferation, differentiation, or apoptosis. ${ }^{37}$ Studies have shown that Egr-1 is low in most human malignant tumor cells and the level of Egr-1 expression is associated with a 5-year survival of cancer patients. In addition, Egr-1 is able to increase the sensitivity of cancer patients to radiotherapy and chemotherapy. ${ }^{38}$ However, the role of Egr-1 in HCC is a controversial topic. Peng et a ${ }^{16}{ }^{16}$ reported that Egr-1 promotes hypoxia-induced autophagy to enhance chemo-resistance of hepatocellular carcinoma cells. Conversely, Shan et al ${ }^{15}$ reported that reexpression of Egr-1 decreased cell growth and tumorigenicity in nude mice.

In the present study, we found that, after silencing Egr-1, the proliferation rate of HepG2 cells was significantly increased, and the effect of inhibition proliferation and promoting apoptosis of the combinations of $\mathrm{As}_{2} \mathrm{O}_{3}$ and 


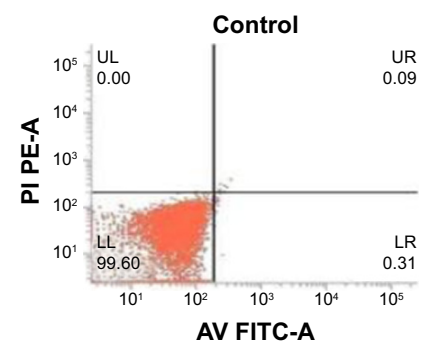

NC

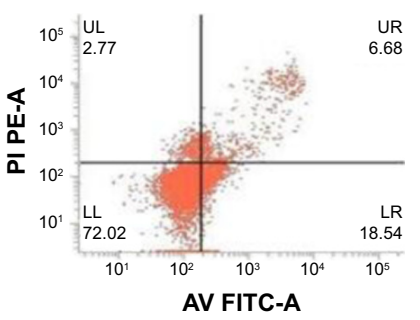

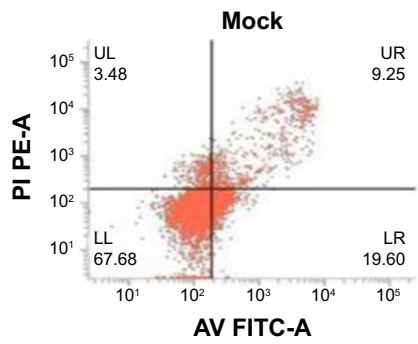

Egr-1 siRNA

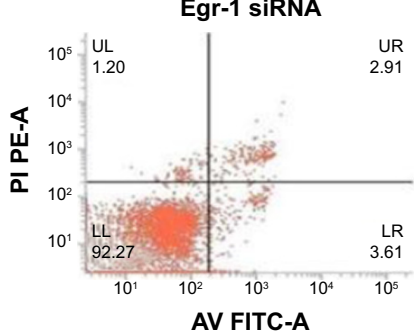

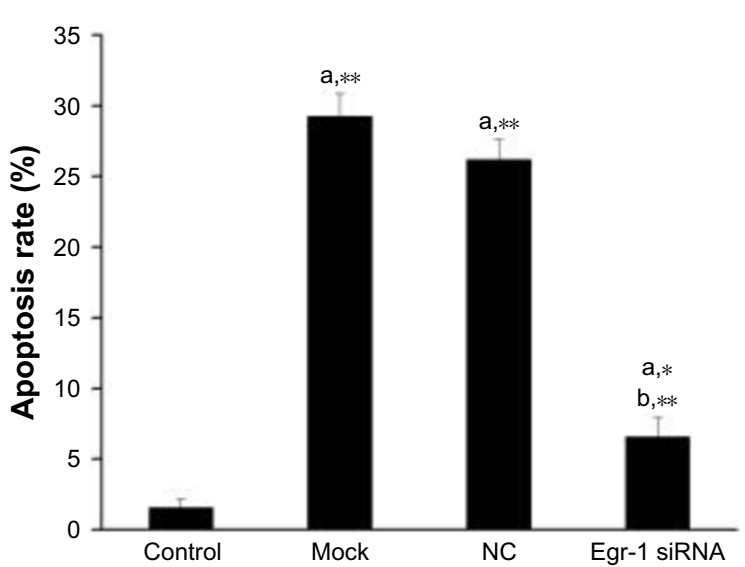

Figure 4 Effects of $\mathrm{As}_{2} \mathrm{O}_{3}$ combined with AZT on cell apoptosis.

Notes: ${ }^{2}$ Compared with blank control group, $* P<0.05$, $* * P<0.01$; b compared with HepG2 or HepG2/NC, $* * P<0.01$.

Abbreviations: $\mathrm{As}_{2} \mathrm{O}_{3}$, arsenic trioxide; AV FITC-A, Annexin $\mathrm{V}$ fluorescein isothiocyanate-area; AZT, 3'-azido-3'-deoxythymidine; Egr-I, early growth response protein I; LL, lower left; LR, lower right; NC, negative control; PE-A, phycoerythrin-area under the curve; PI, propidium iodide; UL, upper left; UR, upper right.

A

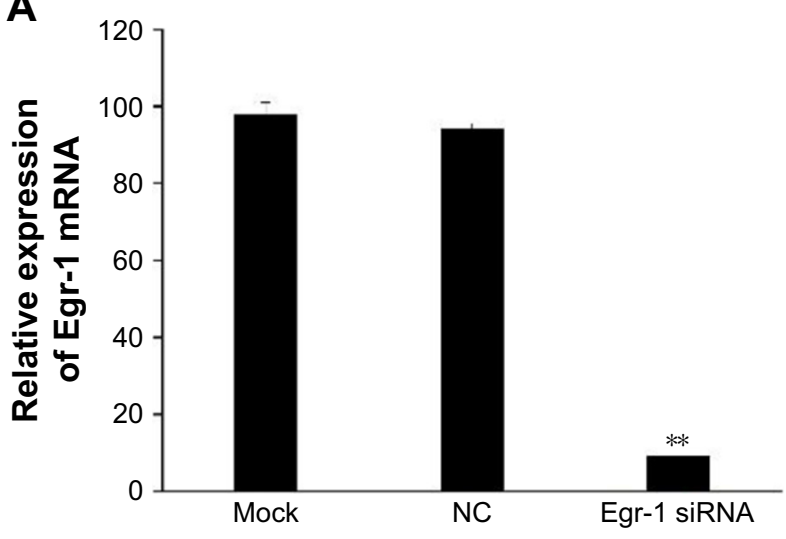

B

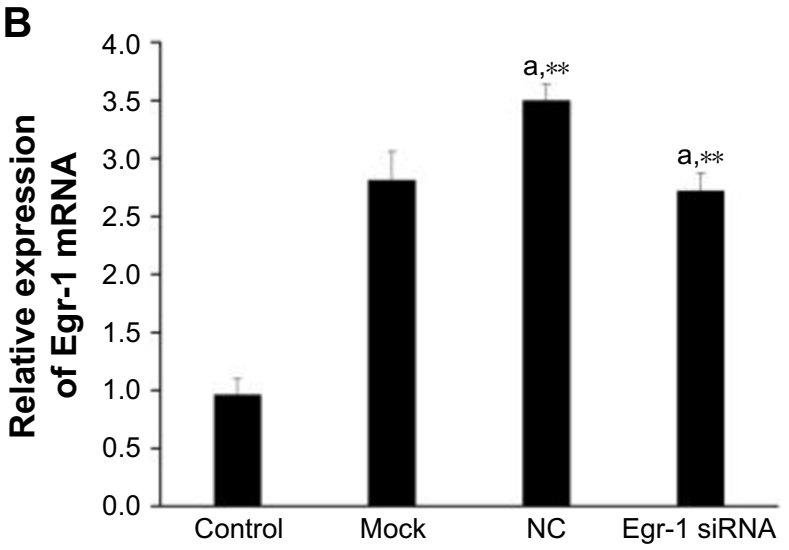

Figure 5 Relative expression of Egr-I mRNA in HepG2 cells.

Notes: (A) Compared with mock or HepG2/NC group, ${ }^{* * P}<0.01$. (B) a Compared with blank control group, $* * P<0.01$.

Abbreviations: Egr-I, early growth response protein I; NC, negative control.

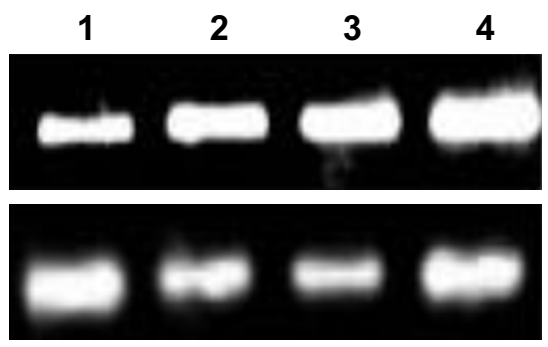

Egr-1

$\beta$-actin

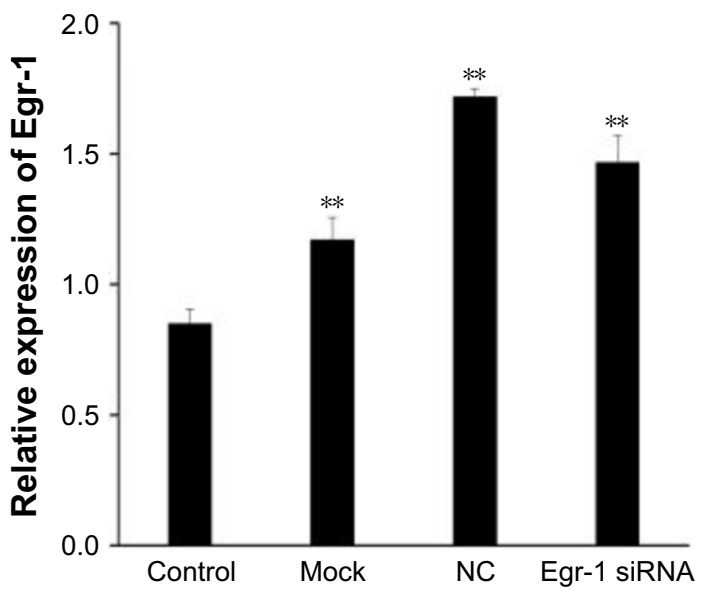

Figure 6 The expression levels of Egr-I protein in HepG2 cells $(n=3)$.

Note: Compared with control, $* * P<0.01$.

Abbreviations: Egr-I, early growth response protein I; NC, negative control. 


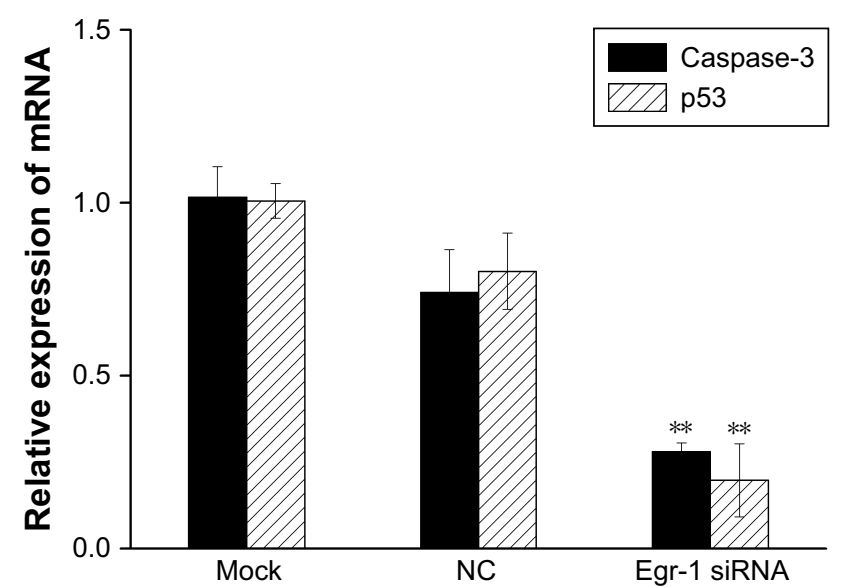

Figure 7 The effect of Egr-I on expression of p53 and caspase- 3 mRNA in HepG2 cells.

Notes: Mock, adding the same amount of culture medium; NC, transfection of nonspecific sequence; Egr-I siRNA, transfected with Egr-I siRNA; compared with mock group or $\mathrm{NC}$ group, $* * \mathrm{P}<0.01$.

Abbreviations: Egr-I, early growth response protein I; NC, negative control.

AZT on HepG2 cells was attenuated. In addition, the CI value was greater than 1 , showing antagonistic effect. Our further results showed that the combination of $\mathrm{As}_{2} \mathrm{O}_{3}$ with AZT could significantly enhance the expression of p53 and caspase-3, but the effect was decreased after silencing Egr-1. These results suggested that Egr-1, which could control the

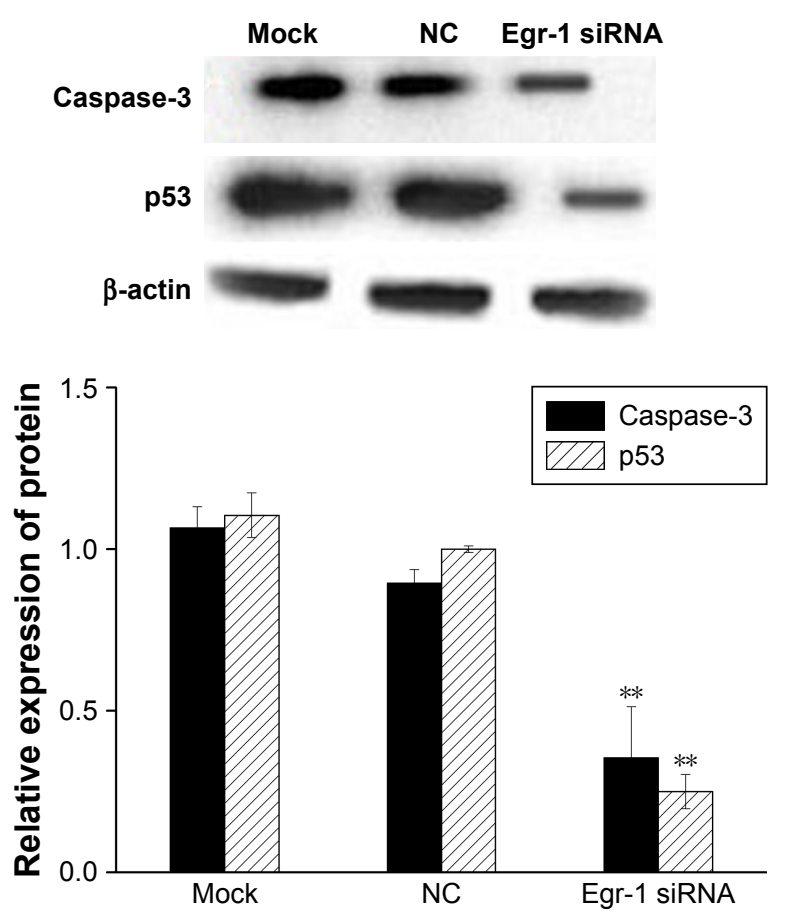

Figure 8 The effect of Egr-I on expression of p53 and caspase-3 protein in HepG2 cells.

Notes: Mock, adding the same amount of culture medium; NC, transfection of nonspecific sequence, Egr-I siRNA, transfected with Egr-I siRNA; compared with mock group or NC group, ${ }^{* * P}<0.01$.

Abbreviations: Egr-I, early growth response protein I; NC, negative control. expression of p53 and caspase-3, may be the key target of the combination of $\mathrm{As}_{2} \mathrm{O}_{3}$ with $\mathrm{AZT}$ on treating hepatocellular carcinoma. Although these findings have potential clinical significance, it is still crucial to further investigate interconnections of Egr-1 among associated signaling nets of hepatocellular carcinoma.

\section{Acknowledgment}

This study was supported by National Natural Science Foundation of China (number 81460456) and Natural Science Foundation of Gansu Province (number 1308RJZA169).

\section{Disclosure}

The authors reports no conflicts of interest in this work.

\section{References}

1. Wang X, Zhang A, Sun H. Power of metabolomics in diagnosis and biomarker discovery of hepatocellular carcinoma. Hepatology. 2013;57:2072-2077.

2. Chaffer CL, Weinberg RA. A perspective on cancer cell metastasis. Science. 2011;331:1559-1564.

3. Ezaki T. Hepatocellular carcinoma: referral to a specialist centre is recommended. BMJ. 1992;304(6821):196-197.

4. Fox E, Razzouk BI, Widemann BC, et al. Phase 1 trial and pharmacokinetic study of arsenic trioxide in children and adolescents with refractory or relapsed acute leukemia, including acute promyelocytic leukemia or lymphoma. Blood. 2008;111:566-573.

5. Wang H, Liu Y, Wang X, et al. Randomized clinical control study of locoregional therapy combined with arsenic trioxide for the treatment of hepatocellular carcinoma. Cancer. 2015;121(17):2917-2925.

6. Hoffman EA, Gizelska K, Mirowski M, Mielicki W. Arsenic trioxide downregulates cancer procoagulant activity in MCF-7 and WM-115 cell lines in vitro. Contemp Oncol (Pozn). 2015;19(2):108-112.

7. Falcone A, Lencioni M, Brunetti I, et al. Maximum tolerable doses of intravenous zidovudine in combination with 5-fluorouracil and leucovorin in metastatic colorectal cancer patients. Clinical evidence of significant antitumor activity and enhancement of zidovudine-induced DNA single strand breaks in peripheral nuclear blood cells. Ann Oncol. 1997;8:539-545.

8. Falcone A, Danesi R, Dargenio F, et al. Intravenous azidothymidine with fluorouracil and leucovorin: a phase I-II study in previously untreated metastatic colorectal cancer patients. J Clin Oncol. 1996; 14:729-736.

9. Chen C, Zhang Y, Wang Y, Huang D, Xi Y, Qi Y. Synergic effect of 3-azido-3-deoxythymidine and arsenic trioxide in suppressing hepatoma cells. Anticancer Drugs. 2011(22):435-443.

10. Liu Y, Yuan LY, Chu HY, Chen C. As2O3 in combination with AZT suppresses the proliferation of hepatoma HepG2 cells through activating caspase-3 pathway. Tumor. 2014;34(8):705-711.

11. Han L, Chen C, Chu HY, Liu Y, Liang Y, Li J. Effects of As2O3 combined with AZT on migration and invasion of liver cancer HepG2 cells. Tumor. 2015;35(9):982-989.

12. Cui W, Hu JL, Kong LL, et al. [Increased chemotherapy sensitivity on adriamycin resistance cells of breast cancer by up-regulated EGR-1]. Chin J Cancer Prevent Treat. 2009;16(10):744-747. Chinese.

13. Baron V, Adamson ED, Calogero A, Ragona G, Mercola D. The transcription factor Egr1 is a direct regulator of multiple tumor suppressors including TGF- $\beta 1$, PTEN, p53, and fibronectin. Cancer Gene Ther. 2006;13:115-124. 
14. Ragione FD, Cucciolla V, Criniti V, Indaco S, Borriello A, Zappia V. p21Cip1 gene expression is modulated by Egr-1: a novel regulatory mechanism involved in the resveratrol antiproliferative effect. Biol Chem. 2003;278:23360-23368.

15. Shan J, Balasubramanian MN, Donelan W, et al. A MEK-dependent transcriptional program controls activation of the early growth response 1 (EGR1) gene during amino acid limitation. J Biol Chem. 2014;289(35): 24665-24679.

16. Peng WX, Xiong EM, Ge L, et al. Egr-1 promotes hypoxia-induced autophagy to enhance chemo-resistance of hepatocellular carcinoma cells. Exp Cell Res. 2016;340(1):62-70.

17. Ma Y, Wang J, Liu L, et al. Genistein potentiates the effect of arsenic trioxide against human hepatocellular carcinoma: role of Akt and nuclear factor- $\kappa$ B. Cancer Lett. 2011;301(1):75-84.

18. Shao QS, Ye ZY, Ling ZQ, Ke JJ. Cell cycle arrest and apoptotic cell death in cultured human gastric carcinoma cells mediated by arsenic trioxide. World J Gastroenterol. 2005;11(22):3451-3456.

19. Wang X, Gao P, Long M, et al. Essential role of cell cycle regulatory genes p21 and p27 expression in inhibition of breast cancer cells by arsenic trioxide. Med Oncol. 2011;28(4):1225-1254.

20. Zhao J, Wang C, Song Y, Fang B. Arsenic trioxide and microRNA204 display contrary effects on regulating adipogenic and osteogenic differentiation of mesenchymal stem cells in aplastic anemia. Acta Biochim Biophys Sin (Shanghai). 2014;46(10):885-893.

21. Zhang Y, Sun M, Shi W, Yang Q, et al. Arsenic trioxide suppresses transcription of hTERT through down-regulation of multiple transcription factors in HL-60 leukemia cells. Toxicol Lett. 2015;232(2): 481-489.

22. Yang X, An L, Li X. Arsenic trioxide induced endoplasmic reticulum stress in laryngeal squamous cell line Hep-2 cells. Auris Nasus Larynx. 2014;41(1):81-83.

23. Lo-Coco F, Avvisati G, Vignetti M, et al. Retinoic acid and arsenic trioxide for acute promyelocytic leukemia. N Engl J Med. 2013;369(2): 111-121.

24. Shen ZX, Shi ZZ, Fang J, et al. All-trans retinoic acid/As2O3 combination yields a high quality remission and survival in newly diagnosed acute promyelocytic leukemia. Proc Natl Acad Sci USA. 2004; 101(15):5328-5335.

25. Jin RR, Chao R, Xi YM, et al. [Effects of AZT on leukemia cell line KG-1a proliferation and telomerase activity]. Zhongguo Shi Yan Xue Ye Xue Za Zhi. 2012;20(002):277-281. Chinese.
26. He M, Jiang YY, Zhu M, et al. [Effects of 3'-azido-deoxythymidine on telomerase activity and protein expression of hepatocarcinoma cell line SMMC-7721]. Ai Zheng. 2006;25(5):543-548. Chinese.

27. Chen W, Zhang Q, Wu D, Deng L. [Study on tumor cell lines and their telomerase activity by telomerase inhibitors]. Tumor. 2000;6:009. Chinese.

28. Matteucci C, Minutolo A, Marino-Merlo F, et al. Characterization of the enhanced apoptotic response to azidothymidine by pharmacological inhibition of NF-kB. Life Sci. 2015;127:90-97.

29. Sabokrouh A, Vaisiraygani A, Goodarzi MT, et al. Comparison between platinum- azidothymidine and azidothymidine effects on Bcl-2 and telomerase gene expression in rats with hepatocellular carcinoma. Avicenna J Med Biotechnol. 2015;7(2):50-56.

30. Sun R, Eriksson S, Wang L. Identification and characterization of mitochondrial factors modulating thymidine kinase 2 activity. Nucleosides Nucleotides Nucleic Acids. 2010;29(4-6):382-385.

31. Scruggs ER, Dirks Naylor AJ. Mechanisms of zidovudine-induced mitochondrial toxicity and myopathy. Pharmacology. 2008;82(2):83-88.

32. Sun YQ, Guo TK, Xi YM, Chen C, Wang J, Wang ZR. Effects of AZT and RNA-protein complex (FA-2-b-beta) extracted from Liang Jin mushroom on apoptosis of gastric cancer cells. World J Gastroenterol. 2007;13(31):4185-4191.

33. Mattson DM, Ahmad IM, Dayal D, et al. Cisplatin combined with zidovudine enhances cytotoxicity and oxidative stress in human head and neck cancer cells via a thiol-dependent mechanism. Free Radic Biol Med. 2009;46(2):232-237.

34. Johnston JS, Johnson A, Gan Y, Wientjes MG, Au JL. Synergy between 3'-azido-3' deoxythymidine and paclitaxel in human pharynx $\mathrm{FaDu}$ cells. Pharm Res. 2003;20(7):957-961.

35. Chau D, Ng K, Chan TSY, et al. Azacytidine sensitizes acute myeloid leukemia cells to arsenic trioxide by up-regulating the arsenic transporter aquaglyceroporin 9. J Hematol Oncol. 2015;8:46.

36. Wang LN, Li ZJ, Xi YM. [Effect of Emodin Combined with AZT on the proliferation and the expression of BCL-2, NF- $\mathrm{BB}$, TGF- $\beta$ in the leukemia stem cells-KG-1a cells]. Zhongguo Shi Yan Xue Ye Xue Za Zhi. 2015;23(5):1265-1271. Chinese.

37. Pagel JI, Deindl E. Early growth response 1-a transcription factor in the crossfire of signal transduction cascades. Indian J Biochem Biophys. 2011;25(8):226-235.

38. Gitenay D, Baron VT. Is EGR1 a potential target for prostate cancer therapy? Future Oncol. 2009;5(7):993-1003.
OncoTargets and Therapy

\section{Publish your work in this journal}

OncoTargets and Therapy is an international, peer-reviewed, open access journal focusing on the pathological basis of all cancers, potential targets for therapy and treatment protocols employed to improve the management of cancer patients. The journal also focuses on the impact of management programs and new therapeutic agents and protocols on

\section{Dovepress}

patient perspectives such as quality of life, adherence and satisfaction. The manuscript management system is completely online and includes a very quick and fair peer-review system, which is all easy to use. Visit http://www.dovepress.com/testimonials.php to read real quotes from published authors. 